\title{
Stages of Corporate Governance in Transition Economies
}

\author{
Son A. Le \\ Louisiana Tech University • Ruston, LA \\ Mark J. Kroll \\ University of Texas at Brownsville • Brownsville, TX \\ Bruce A. Walters \\ Louisiana Tech University • Ruston, LA
}

\section{Abstract}

We develop a model of corporate governance stages in transition economies, including bureaucratic control-based; relational; and rule, market-based corporate governance. We demonstrate how institutions shape stakeholders' dominant sources of control power and firms' dominant origins of resources within and across these stages. We then theorize how these driving forces influence the effectiveness of these corporate governance stages, and how the shift from one stage of corporate governance to another comes about. Our paper therefore contributes to the understanding of the development and nature of corporate governance in transition economies.

\section{Introduction}

Transition economies are former socialist countries such as those that were part of the former Soviet Union, those in Eastern Europe, and East Asia, which are transforming from central planning to free market competition (World Bank, 2002). Numerous studies of corporate governance in transition economies have recently been undertaken (e.g., Andreff, 1999; Aoki, 1994; Berglof, 1995; Dharwadkar, George, \& Brandes, 2000; Estrin \& Angelucci, 2003; Wright, Filatotchev, Buck, \& Bishop, 2003; Young, Peng, Ahlstrom, \& Bruton, 2002). Notably, transition economies account for a significant portion of the world's population and economic activity, and corporate governance is central to the privatization of state-owned enterprises - a vital activity in their economic transformation (McCarthy \& Puffer, 2003; Peng, 2004). These economies present a unique context for examining phenomena and theories well established in the setting of developed economies (Hoskisson, Eden, Lau, \& Wright, 2000; Peng, 2003).

Most prior studies are static in nature. Given radical institutional changes and varying rates of progress occurring in different transition economies, research insights obtained from such static studies may be inconclusive and not reflective of temporal dimensions of corporate governance within and across transition econo- 
mies. For example, Judge, Naoumova, and Koutzevol (2003) and Peng (2004) found inconsistent results concerning the role of outside board members in Russia and China. Similarly, Wright et al. (2003) and Estrin and Angelucci (2003) reported conflicting findings regarding the effectiveness of inside versus outside ownership. Such inconclusive findings may lead some scholars to conclude that transition economies are heterogeneous and thus it is not feasible to develop a general model of corporate governance for transition economies. However, according to a number of transition economy researchers (e.g., Boisot \& Child, 1996; Le, Kroll, \& Walters, 2010; McMillan \& Woodruff, 2000; Peng, 2003), these findings offer evidence that transition economies go through similar stages during their market-oriented transformation, and at a given point in time their corporate governance is dissimilar because they are in different transition stages.

This paper is motivated by unresolved questions concerning corporate governance in transition economies: (1) Does transition to a market-oriented economy generally progress through similar stages? (2) Which modes of governance are likely effective in those stages? (3) How and when do privatized firms shift from one mode of corporate governance to another? We note that our focus is on corporate governance in privatized firms (firms that have their ownership transferred from a socialist state to private organizations and individuals), to which we refer as "firms" in the rest of the paper. Previous studies (e.g., King, 2001; Le et al., 2010; Peng, 2003) indicate that the market transformation in transition economies can be temporally divided into three stages: (1) the early or bureaucratic control stage, (2) the intermediate or relational stage, and (3) the late or market stage. We suggest that, correspondingly, the prevalent mode of corporate governance likely shifts from bureaucratic control-based to relational corporate governance, then from relational to market-based corporate governance. Drawing on agency, social and political, resource dependence, and neoinstitutional theories, we propose two primary determinants of the shifts in corporate governance modes: the sources of control power available to protect stakeholders' rights (i.e., the power of the state, relational networks, or the market) and the origins of resources firms need to survive and grow (i.e., resources from the state, relational networks, or the market). We posit that a particular institutional framework gives rise to a certain dominant source of power and resources. Those dominant sources determine the most prevalent and effective mode of governance. Radical institutional changes alter the dominant sources of control power and resources, triggering a shift from one mode of governance to another.

Our paper offers the following contributions. First, we propose a general model of corporate governance that specifies the sequential prevalence of three gov- 
ernance modes (i.e., bureaucratic control-based; relational; and rule, market-based corporate governance). Second, we provide insights into relationships linking institutions and institutional changes to sources of power and factors of production, and then to the effectiveness of corporate governance. Finally, we shed light on which mode and related governance mechanisms are likely effective in various stages, as well as when a firm shifts from one governance mode to another.

\section{Corporate Governance in Transition Economies}

\section{Stages of Market Transformation}

Transition economies are former centrally planned economies undergoing unprecedented, comprehensive transformations to market-driven economies (World Bank, 2002). Planned and market economies are opposing economic systems adhering to different institutional frameworks (King, 2001; Martin, 2002; Peng, 2003; Williamson, 1995). An institutional framework is a set of formal constraints such as legal and regulative systems; and informal constraints such as social values, codes of conduct, norms of behavior, and conventions that regulate human behavior and economic activity (e.g., the use of norms of trade associations to regulate exchanges; social pressure to ensure that parties perform their duties) (North, 1990; Scott, 1995). The institutional framework associated with a centrally planned economy, which we label the bureaucratic control institutional framework, principally underlies public ownership, state coordination, redistribution, and control (Boisot \& Child, 1988; Kornai, 1990). The institutional framework associated with a market economy (market institutional framework) principally underlies private ownership and market transactions (Kornai, 1990; Williamson, 1995).

Institutional theorists assert that the replacement of an institutional framework with a new one often occurs in three stages: dominance of the old framework, emergence of an interim framework with some elements of both frameworks, and finally prevalence of a new framework (Benson, 1977; Gerry, 2000; Lachmann, 1979; North, 1990). We suggest transformation from bureaucratic control to the market institutional framework is likely to go through an interim (intermediate) stage, during which the formal rules associated with the centrally planned system weaken rapidly. The new market rules evolve slowly, forcing various constituents to rely on informal constraints (Lachmann, 1979; McMillan \& Woodruff, 2000; Peng, 2003; Peng $\&$ Heath, 1996). The intermediate period therefore can be defined as the relational stage dominated by a relational institutional framework (Peng, 2003). Although one institutional framework is dominant in a particular stage, the three institutional 
frameworks tend to coexist during the transition process, and together constitute a larger societal institutional environment (Benson, 1977; North, 1990).

Extant literature on transition economies documents the existence of three stages. The factors inherent in the bureaucratic control stage (i.e., state ownership, intervention, and redistribution) have been reported in various studies (e.g., Andreff, 1999; King, 2001; Kornai, 1990; McCarthy \& Puffer, 2003; Stark, 1994; Suhomlinova, 1999). Andreff (1999) showed that in 1995, after six years of transition, the average state ownership in former socialist economies in Central and Eastern Europe was 58 percent; among them the Czech Republic had the lowest level of state ownership (31\%), and Tajikistan and Turkmenistan had the highest (85\%). The existence of a relational stage is also well documented (e.g., King, 2001; McMillan \& Woodruff, 2000; Peng, 2003; Peng \& Heath, 1996). These studies have demonstrated that widespread, relationship-based exchange tends to emerge systematically in transition economies due to the absence of formal, market-based laws and regulations. Finally, some transition economies (e.g., those of the Czech Republic and Poland) have now progressed to the late stage of transition as they now have an advanced market institutional framework (Tihanyi \& Roath, 2002).

We do not focus on the investigation of how transition economies progress. Instead, we assume transition economies are committed to transforming to a market economy and are likely to go through the three stages we specify. We believe that bracketing the transition process into different stages with fairly distinct institutional trajectories is useful in examining the impact of institutions and institutional changes on corporate governance in transition economies.

\section{Stages of Corporate Governance}

Corporate governance can be thought of as a form of exchange as it provides an exchange structure for stakeholders (Jensen \& Meckling, 1976; Shleifer \& Vishny, 1997; Williamson, 1985). Literature indicates that different forms of corporate governance emerge in different stages of the transformation from centrally planned to market-based systems in transition economies (King, 2001; McMillan $\&$ Woodruff, 2000; Peng, 2003). Consistent with these transformation stages, there exist three forms of corporate governance, temporally including bureaucratic control-based, relational, and market-based forms. Bureaucratic control-based corporate governance is characterized by hierarchical and bureaucratic structures and controls (Boisot \& Child, 1988; Eggertsson, 1990; Kornai, 1990). For example, the state and its agencies directly control firms using bureaucratic regulations. Relational gover- 
nance is the form of control in which stakeholders rely on informal constraints and self-enforcement (i.e., social relationships, social norms, and personal power) to create pressures and sanctions against opportunistic behaviors (McMillan \& Woodruff, 2000; Ouchi, 1979). Market-based governance includes the market for corporate control and the managerial labor market described in mainstream governance literature (e.g., Jensen, 1993; La Porta, Lopez de Silanes, \& Shleifer, 1998; Shleifer \& Vishny, 1997), and other mechanisms directly or indirectly based on market forces, formal rules, and third-party oversight and enforcement.

The general model provides insights regarding societal or country-level corporate governance in transition economies. The message for firm-level governance is that privatized firms sequentially adopt bureaucratic control-based, relational, and rule-based governance as they move through the transition process. But firms are not likely to reach inflection points between the prevalent modes with the same speed because firms may be embedded in different institutional trajectories. In examining transition economies, therefore, we should identify which institutions have the most significant impact on corporate governance and their dynamics.

\section{Institutions of Corporate Governance in Transition Economies}

To examine the impact of institutions on a focal issue, institutional theorists (e.g., Hoffman, 1999; Scott, 1995) recommend an "organizational field" perspective in setting the boundaries of institutions and constituents relevant to that issue. The corporate governance-based field consists of relevant stakeholders and institutions that impact governance, often referred to as institutions of corporate governance (e.g., Garrod, 2000). Major stakeholders include shareholders, managers, employees, customers, suppliers, and the state (Prowse, 1995). Significant institutions of corporate governance include formal constraints (legal, regulatory, and judicial systems), informal constraints (beliefs, norms, and routines), financial systems, product markets, managerial labor markets, and economic structures (Jensen, 1993; La Porta et al., 1998; Prowse, 1995; McCarthy \& Puffer, 2003; Roe, 1991; Shleifer \& Vishny, 1997). We briefly review how those institutions influence governance and their dynamics during the transition process.

Legal, regulatory, and judicial systems provide legitimate power for stakeholders to pursue coercive enforcement of property rights, corporate law, and contracts (La Porta et al., 1998). In the early stage, laws and regulations support state control and coordination of economic activities (Boisot \& Child, 1988; King, 2001; Kornai, 1990; Stark, 1994). In the late stage, formal rules enforce property rights 
and market transactions (Peng, 2003; Williamson, 1995). In the intermediate stage, formal rules associated with both centrally planned and market-based systems are weak; so informal rules, private orders, and self-enforcement are typical. Informal constraints exert social pressures and norms on stakeholders (McCarthy \& Puffer, 2003; Ouchi, 1979). Commonly shared informal norms and beliefs in the early stage (e.g., lack of appreciation of property rights, risk aversion, rule avoidance, and reliance on the state) are legacies of the former centrally planned system (Kornai, 1990; Peng \& Heath, 1996). In the late stage, actors are accustomed to an equity culture and formal rules (Suhomlinova, 1999). The intermediate stage is characterized by norms and values that are relationship and network oriented (McMillan \& Woodruff, 2000; Peng \& Heath, 1996).

Financial systems include securities markets, banks, and other financial intermediaries. Securities markets affect publicly listed firms by issuing listing requirements concerning governance and financial disclosure, assessing firm performance (through stock price changes), and creating a market for corporate control (takeovers [Jensen, 1993]). Banks and other financial intermediaries often serve as firm shareholders, so creditors, auditors, and analysts have a profound impact on corporate governance (Berglof, 1995; McCarthy \& Puffer, 2003). Product markets influence governance by exerting competitive pressure and bankruptcy threat on firms (Jensen, 1993). Labor markets influence governance by placing a value on managers' and board members' human capital (Fama, 1980). Financial systems, product markets, and managerial markets gradually develop along the transition process (less developed in the early stage and more so in the late stage). Economic structures refer to the mix of various economic sectors, such as the public, private, and foreign sectors. Private and foreign sectors account for an increasing portion of transition economies. The state-owned sector shrinks as transition unfolds (Suhomlinova, 1999). Changes in economic structures impact governance by affecting the degree of state intervention and the dominance of corporate governance practices associated with firms in different sectors (Dharwadkar et al., 2000). Table 1 summarizes the institutions in different stages of market transformation in transition economies. 
Table 1

\section{Institutions of Corporate Governance in Transition Economies}

\begin{tabular}{|c|c|c|c|}
\hline $\begin{array}{l}\text { Institutions } \\
\text { of Corporate } \\
\text { Governance }\end{array}$ & $\begin{array}{l}\text { Early or } \\
\text { Bureaucratic } \\
\text { Control Stage }\end{array}$ & $\begin{array}{l}\text { Intermediate or } \\
\text { Relational Stage }\end{array}$ & $\begin{array}{l}\text { Late or Market } \\
\text { Stage }\end{array}$ \\
\hline $\begin{array}{l}\text { Formal constraints } \\
\text { (legal and judicial } \\
\text { systems) }\end{array}$ & $\begin{array}{l}\text { Prevalence of } \\
\text { administrative } \\
\text { control-supporting } \\
\text { institutions }\end{array}$ & $\begin{array}{l}\text { Lack of viable formal } \\
\text { institutions }\end{array}$ & $\begin{array}{l}\text { Prevalence of } \\
\text { rule, market } \\
\text { based-supporting } \\
\text { institutions }\end{array}$ \\
\hline $\begin{array}{l}\text { Informal constraints } \\
\text { (norms, social } \\
\text { pressures, } \\
\text { expectations) }\end{array}$ & $\begin{array}{l}\text { Associated with } \\
\text { planned system } \\
\text { Lack of equity } \\
\text { culture }\end{array}$ & $\begin{array}{l}\text { Associated with } \\
\text { social relationships } \\
\text { and networks } \\
\text { Emerging equity } \\
\text { culture }\end{array}$ & $\begin{array}{l}\text { Associated with } \\
\text { market system } \\
\text { More developed } \\
\text { equity culture }\end{array}$ \\
\hline Financial system & $\begin{array}{l}\text { Nascent securities } \\
\text { markets } \\
\text { Banking system as } \\
\text { state tool }\end{array}$ & $\begin{array}{l}\text { Small, illiquid } \\
\text { securities markets; } \\
\text { underdeveloped } \\
\text { banking system }\end{array}$ & $\begin{array}{l}\text { Functioning } \\
\text { securities markets; } \\
\text { improved banking } \\
\text { system }\end{array}$ \\
\hline Product market & $\begin{array}{l}\text { Unsophisticated } \\
\text { demand, low } \\
\text { competition }\end{array}$ & $\begin{array}{l}\text { Low to medium } \\
\text { competition }\end{array}$ & $\begin{array}{l}\text { Medium to high } \\
\text { competition }\end{array}$ \\
\hline $\begin{array}{l}\text { Managerial labor } \\
\text { market }\end{array}$ & $\begin{array}{l}\text { Nascent managerial } \\
\text { labor market }\end{array}$ & $\begin{array}{l}\text { Underdeveloped } \\
\text { managerial market }\end{array}$ & $\begin{array}{l}\text { Functioning } \\
\text { managerial labor } \\
\text { market }\end{array}$ \\
\hline Economic structure & $\begin{array}{l}\text { Dominant state } \\
\text { ownership, } \\
\text { increasing private } \\
\text { ownership, small } \\
\text { foreign ownership } \\
\text { Strong state } \\
\text { intervention }\end{array}$ & $\begin{array}{l}\text { Dominant private } \\
\text { ownership, blurring } \\
\text { ownership, } \\
\text { decreased state } \\
\text { ownership, } \\
\text { increased foreign } \\
\text { ownership } \\
\text { Medium state } \\
\text { intervention }\end{array}$ & $\begin{array}{l}\text { Dominant private } \\
\text { ownership, sizable } \\
\text { foreign ownership, } \\
\text { small state } \\
\text { ownership } \\
\text { Low state } \\
\text { intervention }\end{array}$ \\
\hline
\end{tabular}

We have specified three prevalent modes of corporate governance, their institutions, and their dynamics during the transition process. We now direct our focus to firm-level governance. In what follows, we examine factors that help determine when firms move from one stage of corporate governance to another. 


\section{Determinants of Corporate Governance Modes}

The question of what determines how corporations are governed has been widely studied. Agency theory, a dominant theme in governance research, proposes that the divergent interests of principals (shareholders) and agents (managers) make agency problems inevitable; and thus, the purpose of governance is to minimize agency costs (Eisenhardt, 1989; Jensen \& Meckling, 1976). Resource dependence theory implies that corporate governance is structured to facilitate the acquisition of critical resources (Hillman \& Dalziel, 2003; Pfeffer \& Salancik, 1978). Neo-institutional theorists argue that firms attempt to become isomorphic with their environment in order to obtain legitimacy, stability, and resources necessary for survival (DiMaggio \& Powell, 1983; Meyer \& Rowan, 1977). Proponents of the political and social approaches to corporate governance change (e.g., Davis \& Thompson, 1994; Roe, 1991) argue that efficiency-oriented approaches (e.g., agency and resource dependence theories) fail to explain governance changes in a number of important situations (e.g., takeover barriers). They suggest stakeholders' interests and power, which are politically determined, drive corporate governance (Gouervitch, 2003), more for powerful stakeholders and less for weaker stakeholders (Roe, 1991; Seo \& Creed, 2002).

Drawing from these approaches, we suggest two major determinants of governance in transition economies: (1) the sources of control power stakeholders rely on to protect their interests in the firm, and (2) the origins or providers of resources stakeholders and their firm rely on for the firm's survival and growth. Stakeholders involved in a firm protect their interests, employing some form of power to prevent exploitation (Fama, 1980; Young et al., 2002). This power may come from various sources such as the stakeholders themselves, social networks and relationships, legal systems, and the market (Jensen, 1993; Ouchi, 1979). Institutional changes arising from collective actions of one or more stakeholder classes or other exogenous factors may bring about a new dominant source of control power, changing the nature of governance (Davis \& Thompson, 1994). In sum, the source of power stakeholders primarily rely upon to protect their interests helps determine the characteristics of that firm's corporate governance.

Similarly, the dominant providers of resources strongly impact corporate governance. Because of their interests in the firm, stakeholders are concerned about firm survival and growth. Failure to access critical resources threatens firm survival and stakeholders' interests. To acquire resources, a firm must establish links with primary providers of needed resources (Pfeffer \& Salancik, 1978), and/or conform to 
those providers' expectations (DiMaggio \& Powell, 1983; Meyer \& Rowan, 1977). Stakeholders and their firm likely adopt mechanisms that facilitate acquisition of needed resources (Oliver, 1991). A particular provider of resources may require stakeholders and their firm to employ a particular mode of exchange and governance practices (Suhomlinova, 1999). For instance, the divergence in corporate governance approaches in the U.S. versus Japan is also based on the U.S. firms' reliance on securities markets for capital, whereas firms in Japan often obtain capital from their main bank (Aoki, 1994).

Corporate governance change can be evolutionary and gradual or revolutionary and radical. Evolutionary change occurs within a stage and within the context of an existing orientation or mode, whereas revolutionary change occurs at the points of inflection when one mode is abandoned in favor of another (Greenwood \& Hinings, 1996; North, 1990). We suggest that within each stage or mode of governance, stakeholders rely on a particular dominant source of power, and their firms acquire resources from a particular dominant provider. Within each stage, corporate governance undergoes evolutionary change through which stakeholders tailor their firm's corporate governance in order to enhance their efficiency in employing control power and obtaining resources from existing dominant sources.

When new sources of power and/or resources become more important to firms than the existing ones, stakeholders and their firms undertake revolutionary change in governance to accommodate the new dominant sources. As a result, firms shift their corporate governance from one mode to another. A number of Japanese firms recently gave up their traditional relationships with their banks and turned to the securities markets for capital. They changed their corporate governance practices by providing more financial disclosure and changing their board structure (Yoshikawa \& Phan, 2001). We posit that the shift from one mode of governance to another is motivated by changes in the dominant source of power, the origin of resources, or both. When governance stabilizes within a particular stage, the dominant sources of power and resources are likely to be the same. For example, when the market became the dominant source of capital for the previously mentioned Japanese firms, the market tended to exert more control power over them than did their banks (Yoshikawa \& Phan, 2001). The incompatibility of a firm's dominant sources of control power and resources creates conflict in the firm's corporate governance structure, triggering movement toward the convergence of these sources (Seo \& Creed, 2002). 
Proposition 1: In transition economies, changes in a firm's dominant source of power and/or the origin of resources trigger the firm to shift from one mode of corporate governance to another.

We next examine how institutions of governance and their dynamics during transition influence dominant sources of control power and resources, and thus determine which governance mode is effective in a particular stage and when a firm might shift from one prevalent mode to another.

\section{Shifts in Corporate Governance Modes During the Market Transition}

As described earlier, country-level corporate governance can be bracketed into three temporal stages: bureaucratic control-based, relational, and marketbased. Generally, bureaucratic control-based governance is associated with state administrative power and state redistribution; relational governance is associated with control power and resources derived from networks and social relationships; and market-based governance involves control power and resources flowing from the market. During the institutional transformation process, the three institutional frameworks will to some extent coexist and be more or less prevalent at different stages. We suggest that in a particular stage, most firms adopt the correspondingly prevalent mode of governance, while others may adopt modes contingent on which institutional framework has the most impact on them in terms of resources and control power. Not all firms will have the same combinations of sources of power and resources at a given point in time.

Nine possible combinations of three sources of control power (state, networks, and market) and three sources of factors of production (state, networks, and market) are shown in Figure 1. Of these, most of cell 3 (a combination of market power and state resources) and most of cell 7 (a combination of state power and market resources) are inconsistent with our assumption that transition states commit to market transformation; and they gradually phase out their micro-control over firms in order to facilitate market development. Thus, the most likely combinations are within the shaded area in Figure 1. Lines T1 and T2 represent points of inflection at which a firm shifts from bureaucratic control-based to relational governance, and from relational to market-based governance, respectively. 


\section{Figure 1}

Firm-level Corporate Governance During the Market Transition:

Combinations of Sources of Control Power and Resources, and the Inflection Points
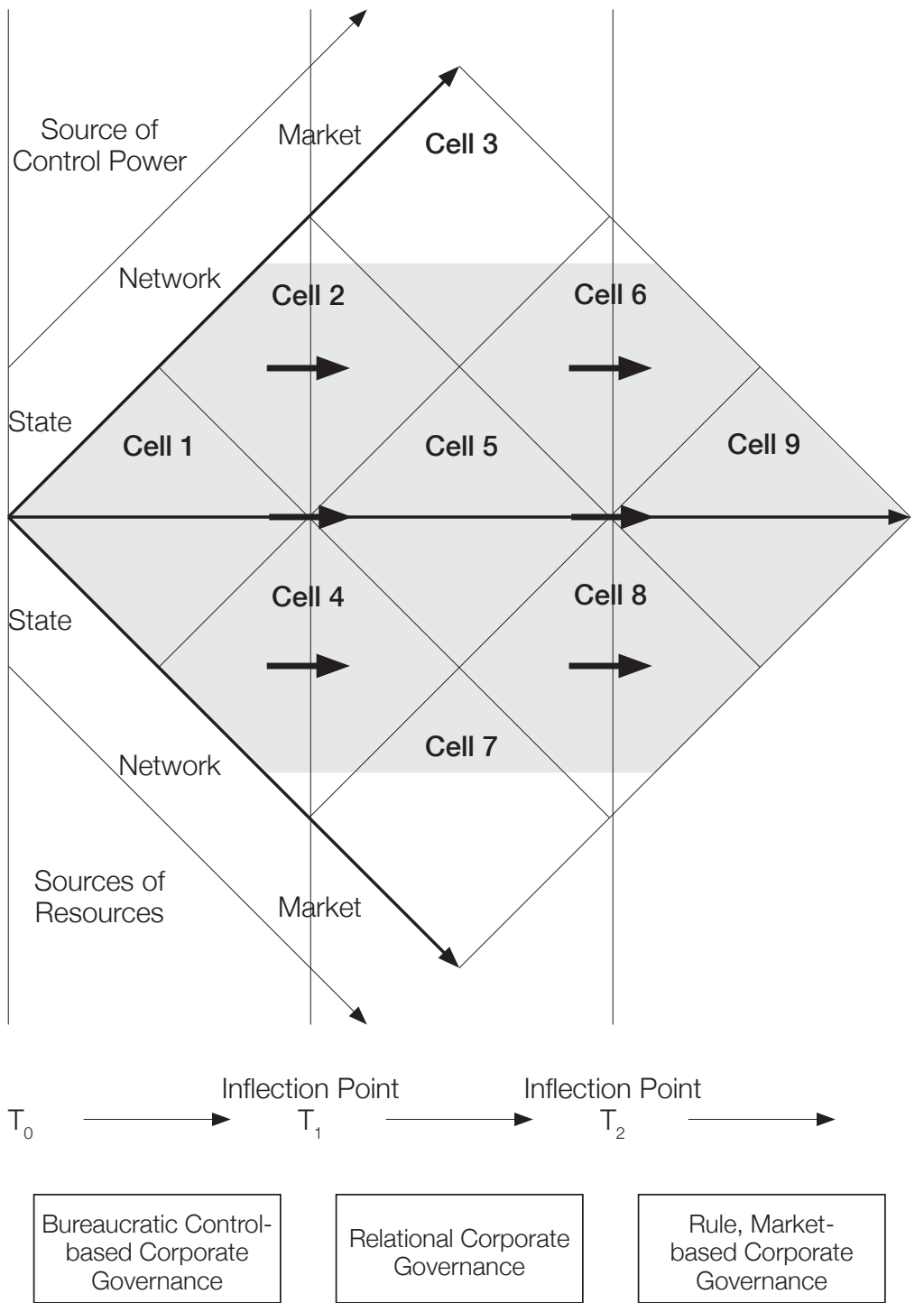

Relational Corporate Governance
Rule, Marketbased Corporate Governance 


\section{The Early Stage: Bureaucratic Control-Based Governance}

In the early stage of transition, a state control-supporting institutional framework prevails. Regardless of the transition approaches (shock therapy or gradualist), in the early stage, transition economies are still largely influenced by the legacies of the past centrally planned system, such as state control, state ownership, soft budgetary constraints, favorable contacts with the state, managerial risk aversion, and rule avoidance (Boisot \& Child, 1988; King, 2001; Kornai, 1990). Laws and rules supporting market-based transactions are lacking or weakly enforced (Williamson, 1995). Economic actors are not accustomed to a culture based on equity and property rights (McMillan \& Woodruff, 2000). The financial system that merely operated as the state budgetary unit in the old system is far from sophisticated enough to support a market economy (Berglof, 1995; Garrod, 2000). Similarly, it takes time for product and labor markets, non-existent in planned economies, to function properly (Peng \& Heath, 1996).

Therefore, in this stage the dominant sources of control power and resources of a firm are likely to be the state (the shaded area covering cell 1 and parts of cells 2 and 4 in Figure 1). Prior studies have demonstrated that transition states either have played or should play a major role in corporate governance in the early transition stage (e.g., McCarthy \& Puffer, 2003). Transition economies' privatization programs carried out using methods such as vouchers, employee/ manager buyouts, and auctions often resulted in concentrated groups of shareholders, such as the state or its designated agencies (e.g., national privatization funds and banks), employees, managers, and stakeholder shareholders (e.g., banks, suppliers, and customers). Among them, the state, regardless of its ownership position in the firm, has the greatest power because of its residual bureaucratic control and redistributive powers (Boisot \& Child, 1988; King, 2001; Kornai, 1990). Other shareholders' power tends to be unbalanced. Inside owner managers are typically central figures as they tend to leverage their positions and their ability to manipulate information in order to take control of their firms (Dharwadkar et al., 2000; King, 2001). Employee shareholders do not generally consider themselves owners of their firms (King, 2001; Martin, 2002). Outside shareholders find it difficult to monitor and discipline managers due to the absence of formal institutions of corporate governance, such as enforceable corporate laws, financial regulations, and market forces (Berglof, 1995; Garrod, 2000; King, 2001; Martin, 2002). Stakeholders have few alternatives but to rely on the state's administrative power to protect their interests in the firm. The state also tends to be the dominant provider of resources due to residual state redistribution 
practices (the collection, storage, and redistribution of goods and services by the state), the embeddedness of both the state and firms in such practices, and the inability of markets and informal networks to channel resources to firms (Kornai, 1990; Nee, 1992).

The foregoing indicates that stakeholders should adopt bureaucratic controlbased mechanisms in the early stage to reduce agency problems and help their firms acquire needed resources from the state. Evidence indicates that when states prepare adequately for the privatization of state-owned firms and maintain bureaucratic control in the early stage (e.g., China, Poland, Czech Republic), agency problems are less rampant (King, 2001). Otherwise, managers may loot firm assets and entrench themselves, resulting in severe agency problems (Dharwadkar et al., 2000; Martin, 2002). Bureaucratic control-based governance has serious limitations, however, such as weak capability, corruption, and little motivation to monitor on the part of state officers (McCarthy \& Puffer, 2003; Suhomlinova, 1999). The prevalence of this mode in the early stage is due less to its inherent effectiveness than to an absence of other modes of governance yet to come into effect.

In sum, in the early stage, stakeholders and their firms should employ corporate governance mechanisms that help secure the state's protection and resources. For example, board members from the state or its agencies, such as ministries and local governments, can help stakeholders to secure state administrative power to protect their interests and obtain firm resources from the state. Stakeholders and their firms will also achieve these objectives by having state ownership, using debt from state-owned banks and financial institutions, and retaining membership in the state's vertical hierarchical structures. Thus:

Proposition 2: In the early stage of transition economies (cell 1 and a portion of cells $2 \& 4$ ), firms that are subject to state control-based corporate governance will attain better performance and a greater chance of survival than firms subject to relational or market-based corporate governance.

\section{The Shift from Bureaucratic Control-Based to Relational Corporate Governance}

When truly committed to market-oriented reforms, transition states are expected over time to develop a market institutional framework and abandon bureaucratic control (Williamson, 1995). Toward the end of the early stage, the institutional framework supporting bureaucratic control will weaken, as will the state's redistri- 
bution systems and administrative power over firms. Meanwhile, institutions supporting market-based transactions are evolving but are still far from being capable of regulating economic transactions (McMillan \& Woodruff, 2000). Such institutional changes alter stakeholders' dominant source of control power and the firms' source of inputs, triggering the shift from bureaucratic control-based to relational governance.

The weakening of state bureaucratic control and the absence of viable formal rules and third-party enforcement compel shareholders to create their own control power or seek control power from networks and relationships to protect their interests. Powerless and unprotected employees and minority shareholders are likely to sell their positions to either managers or other powerful shareholders (King, 2001). Incumbent managers use various tactics to accumulate ownership in their firms, and form alliances with state officials and other firms' managers, further enhancing their power (Dharwadkar et al., 2000; Martin, 2002). Large financial groups and investment funds emerge as powerful shareholders because of political connections and financial strength (McCarthy \& Puffer, 2003). Firms are often controlled by small groups of blockholders with relatively equal power who, in the absence of formal legal constraints, tend to negotiate and establish informal, relational arrangements to prevent individual blockholders from engaging in opportunistic behaviors, thus driving firms to adopt relational corporate governance.

Toward the end of the early stage, state redistribution shrinks, forcing firms to form networks with suppliers, customers, and banks to obtain resources and dispose of outputs (King, 2001; Peng \& Heath, 1996). Due to mutually dependent relationships, firms often engage in cross-holdings and interlocking directorates to facilitate cooperation and safeguard interests (Peng \& Heath, 1996). To obtain resources from networks, stakeholders and their firms are expected to shift from bureaucratic control-based to relational governance. They do so when they come to rely more on networks and social relationships to acquire power and resources than on the state (i.e., line T1 of Figure 2).

Proposition 3.1: Firms experience a point of inflection and transition from bureaucratic control-based to relational corporate governance when their dominant sources of power and resources change from those associated with the state to those associated with networks and relationships.

Not all firms likely experience this inflection point at the same time. In Figure 1 , we suggest that firms shift from bureaucratic control-based to relational gover- 
nance when they experience a diminution in state control power (as in cell 2 at T1), or a reduction in state resources (as in cell 4 at T1), or both (i.e., moving from cell 1 to cell 5). We suggest three primary reasons firms may confront the inflection point and the associated shift from one dominant source of control power and resources to another at different times. First, if firms are essential to state operations and economic and social stability, the state will likely maintain support and control over them (Nee, 1992; Suhomlinova, 1999); and the duration of the state's role as the dominant source of control power and/or resources will be longer. Examples are firms that are large, provide critical products and services, are major employers, and contribute significantly to state revenues. Second, if firms and their stakeholders have the ability to influence the state politically, controlling ministries or state officers, they may shorten or lengthen the duration of state dominance to suit their interests (King, 2001; Martin, 2002). For example, firms and their stakeholders may use political influence to obtain resources from the state for a period longer than would otherwise be warranted, or firms may manipulate the state to secure independence from state control sooner than would otherwise be the case. Third, firms' ability to operate without state control and resources also affects the time needed to reach the inflection point. For macro-economic and social stability reasons, the state is unlikely to abandon firms unable to operate and/or govern themselves independently (Suhomlinova, 1999). On the other hand, firms that can stand by themselves may seek independence from state control sooner (King, 2001). Firms' ability to operate independently depends on the extent to which they were imbedded in former centrally planned systems and their ability and/or opportunity to acquire control power and/or resources from other sources (i.e., networks and social relationships).

Proposition 3.2: The more important a firm is to state operations and economic and social stability, the later it will confront the point of inflection from bureaucratic control-based to relational corporate governance.

Proposition 3.3: The relationship between a firm's ability to influence the state and the length of time until it confronts the point of inflection from bureaucratic control-based to relational governance is moderated by the benefits of being associated with the state.

Proposition 3.4: The sooner a firm can operate independently, the earlier it will reach the point of inflection from bureaucratic controlbased to relational corporate governance. 


\section{The Intermediate Stage: Relational Governance}

In the intermediate stage, the dominant sources of control power and resources are associated with networks and relationships (the shaded area covering cell 5 and parts of cells 2, 3, 4, 6, 7, and 8, bounded by lines T1 and T2 in Figure 1). As they move away from the state's coordination and redistribution system, firms become autonomous and must acquire inputs and dispose of outputs. A market institutional framework capable of providing needed market information and mechanisms to permit firms to trade with unknown parties has yet to emerge (McMillan \& Woodruff, 2000; Williamson, 1995); so firms rely on relationships with traditional customers, suppliers, and banks for resources in order to "muddle through the transition" (McCarthy \& Puffer, 1995). Underdeveloped markets and a lack of legal infrastructure make resource acquisition from unknown parties costly or impossible (McMillan $\&$ Woodruff, 2000), forcing firms to establish and "internalize" transactions within networks (Peng \& Heath, 1996).

Because firms are dependent on networks for resources, networks exert control power (Pfeffer \& Salancik, 1978). Without a viable legal infrastructure and state enforcement, stakeholders must form alliances and networks to create power to protect their interests (King, 2001; Stark, 1994). At this stage, stakeholders and their firms likely rely on networks and relationships for control power and resources. Relational governance mechanisms that can help stakeholders employ control power and acquire resources from networks and relationships include (1) multiple blockholders with equal power, (2) cross-holdings and interlocking directorates with shareholder stakeholders, and (3) borrowing from networks of stakeholders.

Multiple blockholders help prevent "principal-principal agency problems" occurring when legal protection of shareholders' rights is weak. Without a viable institutional framework, dominant shareholders may expropriate other shareholders' wealth or manipulate the firm for their own purposes (Young et al., 2002). Multiple blockholders can suppress one another's attempts to dominate and expropriate other shareholders' wealth. Because they have both ownership in and business relationships with the firm, stakeholder shareholders are motivated to monitor managers to protect their interests (Stark, 1994). Board membership helps stakeholder shareholders control managers and facilitates their relationships with the firm (Aoki, 1994). Similarly, borrowing from network members reduces cash flow managers might misallocate and enhances the network's coordination and control over the firm (Dharwadkar et al., 2000). 
Proposition 4: In the intermediate stage of transition economies, the firms that are subject to relational corporate governance will have higher performance and a greater chance of survival than firms that are subject to bureaucratic or market-based corporate governance.

\section{The Shift from Relational to Market-Based Corporate Governance}

Toward the late stage, a market institutional framework is expected to take shape. Formal rules (e.g., property rights, contract laws, and corporate laws) and state enforcement are more viable and can facilitate impersonal exchanges. Financial systems (securities markets, banks, and financial intermediaries) are more sophisticated and can provide financial services for firms and investors (Williamson, 1995). Relational exchanges involve severe limitations for firms attempting to expand business activities beyond existing network boundaries (North, 1990; Peng, 2003). Relational transactions tend to create inefficiency, corruption, social unfairness, and disorder, so the state and its citizens will likely press for a more viable legal system and formal enforcement mechanisms to overcome the limitations of relational transactions (McCarthy \& Puffer, 2003; McMillan \& Woodruff, 2000). Following the formation of a market institutional framework, we expect firms will start obtaining resources from the market, and stakeholders will increasingly employ control power derived from the market (i.e., they will transition from cell 5 to cell 9, or across T2 in cells 6 and 8 as shown in Figure 1). Stakeholders' and firms' dominant providers of power and resources will shift from networks to the market, driving firms to the point of inflection between relational and market-based governance.

As described earlier, firms form networks in the intermediate stage to obtain resources. In developed economies, firms network to create competitive advantage through long-term relationships (Peng \& Heath, 1996). But in a transition economy, firms network mainly to survive and pursue stakeholders' interests, especially managers', rather than to obtain capabilities and achieve efficiency (King, 2001; McMillan \& Woodruff, 2000). As product markets become increasingly competitive, firms must focus on building capabilities to survive and grow (Peng, 2003). Exchanges confined to a limited network may hinder firms' efficiency and competitiveness. Development of markets may make possible more efficient modes of exchange. Firms extend their exchange relationships beyond their traditional networks when doing so increases profitability and capabilities. For example, firms may want to sell products to new customers, purchase from new suppliers, and obtain financing from new sources (Suhomlinova, 1999). Such inclinations precipitate a shift in the 
firms' dominant sources of inputs as they move away from reliance on networks and toward the market.

The firms' dominant source of power also begins to shift from networks to the market. Stakeholder shareholders may find alternative market exchange mechanisms more effective than direct ownership, and may be less interested in retaining ownership positions in, and business relationships with firms, thus loosening the networks and weakening their power over firms (Yoshikawa \& Phan, 2001). New, more sophisticated investors will make investment decisions based on rational portfolio analysis rather than on relationships (Belev, 2003). Also, enhanced formal rules and enforcement bring more coercive power to bear on managers (La Porta et al., 1998). Finally, securities markets, the market for corporate control, and the managerial labor market take shape and start to exert their discipline on managers (Belev, 2003).

When the market becomes the dominant source of power and resources, firms will likely restructure corporate governance to accommodate that change. For example, firms are expected to become more transparent and provide more financial disclosure, install independent board members and blockholders (not necessarily stakeholder shareholders) to become cost-effective in monitoring managers, and use performance-based compensation to align managers' and shareholders' interests. In sum, the evolution of a market institutional framework facilitates a shift in the dominant sources of inputs and control power from networks to the market, driving the firm to the point of inflection from relational to market-based corporate governance.

Proposition 5.1: Firms arrive at the point of inflection from relational to market-based corporate governance when their dominant sources of control power and resources change from those associated with networks and social relationships to those associated with the market.

Again, not all firms likely arrive at the same time. Factors influencing the timing of the point of inflection include the rate of development of competition in a firm's market, the effectiveness of the firm's networks, and the extent to which the firm is imbedded in these networks. The development of market institutions and competition may vary across sectors and industries (Suhomlinova, 1999). The earlier a firm confronts such institutional and market development, the earlier it will be under competitive pressure to focus on capabilities and competitive advantage, and the earlier it will access new opportunities brought about by market development. Dominant sources of power and resources shift from networks to the market earlier. But the longer the firm's networks help shareholders to maintain control power and the firm to acquire resources more effectively than the market does, the longer the 
firm will postpone changing its corporate governance. Sometimes firms are highly embedded in networks, and are operationally and/or financially locked into relationships with other network members, making it difficult to break out even when they experience network inefficiencies (Yoshikawa \& Phan, 2001). Thus:

Proposition 5.2: The sooner firms are influenced by market institutions and competition, the earlier they reach the point of inflection from relational to market-based governance.

Proposition 5.3: The more effective firms'networks are in helping the firms and their stakeholders to acquire control power and resources, the later they reach the point of inflection from relational to marketbased corporate governance.

Proposition 5.4: The more firms are imbedded in their networks, the later they reach the point of inflection from relational to market-based corporate governance.

\section{The Late Stage: Rule-Based Governance}

As described earlier, when transition economies advance to the late stage, a market institutional framework becomes dominant. The firm and its stakeholders tend to rely on the market for control power and resources, and thus market-based corporate governance becomes effective (cell 9 and a portion of cells 6 and 8 on the right of line T2 in Figure 1). Transition economies may take somewhat different paths and progress toward market economies with some degree of divergence (Martin, 2002). As a result, their corporate governance systems may have distinct features such as ownership-diffused or ownership-concentrated systems, insider- or outsideroriented systems, and/or securities market-based or bank-based systems (Prowse, 1995). Despite the potential for divergence, we argue that their governance will be largely based on formal rules and market forces. For example, German stakeholderoriented governance and American market-based governance are both built on a nexus of laws, regulations and formal enforcement mechanisms, rather than informal rules or state bureaucratic control.

We consider governance mechanisms largely enforced by formal laws and subject to market discipline to represent rule, market-based governance. Williamson (1985) contends that most exchanges in developed economies are realized through "private orders," which in turn can be enforced by formal laws. Some frequently observed rule, market-based corporate governance mechanisms (e.g., blockholders, 
the market for corporate control, the managerial labor market, independent outside board members, and outcome-based compensation schemes) are likely to be effective in the late stage in transition economies, regardless of the path taken (Fama, 1980; Jensen, 1993; Kroll, Wright, Toombs, \& Leavell, 1997; Prowse, 1995; Shleifer \& Vishny, 1997).

Proposition 6: In the late stage of transition characterized by the prevalence of a market institutional framework, firms that are subject to rule, market-based corporate governance will have higher performance than firms subject to bureaucratic or relational corporate governance.

\section{Discussion, Implications, and Limitations}

We assume transition states are committed to the transformation of their economies, and that the transformation process can be bracketed into early, intermediate, and late stages with the prevalence of state bureaucratic control, relational, and market institutional frameworks, respectively. These institutional frameworks imply the dominance of bureaucratic control-based, relational, and market-based corporate governance, temporally. Based on the general direction of country-level corporate governance, we examine firm-level corporate governance in transition economies. We argue that two major determinants of firm-level corporate governance in transition economies are stakeholders' sources of control power and firms' origins of resources.

In the early stage, the dominant sources of control power and resources are the state; and thus, bureaucratic control-based corporate governance tends to be effective. When the relational institutional framework has greater influence on firms than does the bureaucratic control framework, the firms' dominant sources of control power and resources shift from the state to networks and relationships, driving firms to the point of inflection from bureaucratic control-based to relational corporate governance. Firms' role in their economies, ability to influence the state, and ability to operate independent of the state determine the length of time they take to reach the inflection point from bureaucratic control-based to relational corporate governance.

During the intermediate stage, stakeholders and their firms likely employ control power and acquire resources from networks and relationships, and relational corporate governance is effective. As the transition progresses, a market-based institutional framework begins exerting more influence on firms than does the relational framework. Accordingly, the firms' dominant sources of control power and resources shift from networks and relationships to the market, driving firms to the point of 
inflection from relational to rule, market-based governance. The time it takes for firms to reach the second point of inflection depends on such factors as the impact of market institutions and competition, the effectiveness of networks and relationships, and the degree of network imbeddedness. In the late stage, because a market institutional framework prevails, rule, market-based governance mechanisms become most effective.

Our paper offers several contributions and implications. First, we extend the corporate governance literature on transition economies (e.g., Andreff, 1999; Aoki, 1994; Berglof, 1995; Dharwadkar et al., 2000; Wright et al., 2003; Young et al., 2002) by providing a longitudinal, contingency view of governance. We argue that, given the rapid and comprehensive institutional changes that occur in transition economies, institutional frameworks vary from stage to stage, along with corporate governance. We submit that the most effective and thus the most prevalent mode of governance shifts, temporally, from bureaucratic control-based to relational and from relational to market-based corporate governance. We believe our model not only enhances our understanding of the evolution of governance in transition economies but also has implications for future research in this field. Governance studies in transition economies could specify the transition stage to which they seek to generalize and examine. When conducting cross-sectional studies involving a number of transition economies, it is important to ensure that those economies are in the same stage of transition. When testing the explanatory power of theories established in developed economies in the transitional context, one should examine whether their underlying foundations exist in transition economies. For instance, theories premised on market institutions (e.g., the effectiveness of independent outside directors or a well-functioning managerial labor market) are not likely to hold in the early or intermediate transition stages.

Second, we provide insight into the dynamics of macro-institutions and their impact on changes in corporate governance. Prior studies have paid less attention to institutions' role in corporate governance (Gouervitch, 2003). As described previously, we propose two major determinants (source of power and origin of resources) linking institutions and institutional changes to the effectiveness of, and changes in corporate governance. We draw from agency, resource dependence, and institutional theories, as well as the social and political perspectives of corporate governance, to explain the effects of institutions and institutional changes on these determinants, and in turn on the effectiveness of governance during transition. In the context of rapid institutional change, corporate governance is driven by various forces and should be explained using multiple perspectives. Future studies could adopt other 
perspectives, such as ecology and neo-institutional theories, to identify potential forces and mechanisms that link macro-institutions with the evolution of transition corporate governance.

Third, we offer insight into which mode and related governance mechanism is likely effective at a given stage and when a firm is likely to shift from one mode of governance to another. These insights have practical implications for policy-makers and stakeholders in transition economies as they structure their firms' corporate governance in various transition stages. For example, states in transition should take into account institutional developments in order to implement relevant policies concerning governance. The Washington Consensus approach of rapid elimination of state administrative control proved ineffective (Martin, 2002). Requiring firms to have independent directors in early or intermediate stages when managerial labor markets are still quiescent is likely ineffective (Peng, 2004). At the firm level, our paper implies that stakeholders in transition economies should consider the dominant sources of control power and resources in structuring firms' corporate governance during and across various stages.

Our paper also has limitations. Our model is based on the assumption that states in transition commit to market reforms, and thus the transition process tends to move through the three stages. This assumption is consistent with evidence documented in the extant literature on transition economies (e.g., Andreff, 1999; King, 2001; Kornai, 1990; McCarthy \& Puffer, 2003; Stark, 1994; Suhomlinova, 1999) and with the economics perspective of institutional theory concerning institutional change (e.g., Eggertsson, 1990; Gerry, 2000; Greenwood \& Hinings, 1996; North, 1990). Market transformation in some transition economies may be inconsistent with our assumption due to state ideologies (e.g., retaining socialism) or political and social crises (e.g., state malfunctioning and social disorder). Also, because of the scope and purpose of our paper, we only focus on examining the impact of macro-institutions on governance and do not assess the role of stakeholders and their firms as change agents of macro-institutions. Finally, other types of firms such as private start-ups and foreign-owned firms play increasingly important roles in transition economies (Peng $\&$ Heath, 1996), and our model applies primarily to privatized firms.

\section{References}

Andreff, W. (1999). Privatization and corporate governance in transition countries: Quantitative success and qualitative failure. Management International, 4, 11-30.

Aoki, M. H. (1994). The contingent governance of teams: Analysis of institutional complementary. International Economic Review, 35, 657-676. 
Benson, J. K. (1977). Organizations: A dialectic view. Administrative Science Quarterly, 22, 1-21.

Belev, B. (2003). Institutional investors in Bulgarian corporate governance reform: Obstacles or facilitators? Journal of World Business, 38, 361-374.

Berglof, E. (1995). Corporate governance in transitional economies: The theory and its policy implications in M. Aoki and H. K. Kim, (Eds.), Corporate governance in transitional economies: Insider control and the role of banks. Washington: The World Bank, pp. 59-98.

Boisot, M., \& Child, J. (1988). The iron law of fiefs: Bureaucratic failure and the problem of governance in the Chinese economic reforms. Administrative Science Quarterly, 33, 507-527.

Buck, T., Filatotchev, I., Demina, N. , \& Wright, M. (2003). Insider ownership, human resource strategies and performance in a transition economy. Journal of International Business Studies, 34, 530-549.

Davis, G. F., \& Thompson, T. R. (1994). A social movement perspective on corporate control. Administrative Science Quarterly, 39, 141-173.

Dharwadkar, R., George, G., \& Brandes, P. (2000). Privatization in emerging economies: An agency theory perspective. Academy of Management Review, 25, 650669.

DiMaggio, P. J., \& Powell, W. W. (1983). The iron cage revisited: Institutional isomorphism and collective rationality in organizational fields. American Sociological Review, 48, 147-160.

Eggertsson, T. (1990). Economic behavior and institutions. New York: Cambridge University Press.

Eisenhardt, K. M. (1989). Agency theory: An assessment and review. Academy of Management Review, 14, 57-75.

Estrin, S., \& Angelucci, M. (2003). Ownership, competition and enterprise performance. Comparative Economic Studies, 45, 173-188.

Fama, E. F. (1980). Agency problems and the theory of the firm. Journal of Political Economy, 88, 288-307.

Garrod, N. (2000). Environmental contingencies and sustainable modes of corporate governance. Journal of Accounting and Public Policy, 19, 237-261.

Gerry, J. (2000). Microprocesses of institutional change in the context of privatization, Academy of Management Review, 25, 572-581.

Gouervitch, P. A. (2003). The politics of corporate governance regulation. The Yale Law Journal, 112, 1829-1880. 
Greenwood, R., \& Hinings, C. R. (1996). Understanding radical organizational change: Bringing together the old and the new institutionalism. Academy of Management Review, 21, 1022-1055.

Hillman, A. J., \& Dalziel, T. (2003). Boards of directors and firm performance: Integrating agency and resource dependence perspectives. Academy of Management Review, 28, 383-396.

Hoffman, A. J. (1999). Institutional evolution and change: Environmentalism and the U.S. chemical industry. Academy of Management Journal, 42, 351-371.

Hoskisson, R. E., Eden, L., Lau, C. M., \& Wright, M. (2000). Strategy in emerging economies. Academy of Management Journal, 43, 249-267.

Jensen, M. C. (1993). The modern industrial revolution, exit, and the failure of internal control systems. The Journal of Finance, 48, 831-880.

Jensen, M. C., \& Meckling, W. H. (1976). Theory of the firm: Managerial behavior, agency costs and ownership structure. Journal of Financial Economics, 3, 305360 .

Judge, W. Q., Naoumova, I., \& Koutzevol, N. (2003). Corporate governance and firm performance in Russia: An empirical study. Journal of World Business, 38, 385-396.

King, L. P. (2001). The basic features of postcommunist capitalism in Eastern Europe: Firms in Hungary, the Czech Republic, and Slovakia, Westport, CT: Praeger

Kornai, J. (1990). The road to a free economy. New York: Norton.

Kroll, M. J., Wright, P., Toombs, L. A., \& Leavell, H. (1997). Form of control: Critical determinant of acquisition performance and CEO rewards. Strategic Management Journal, 18, 85-96.

La Porta, R., Lopez de Silanes, F., \& Shleifer, A. (1998). Corporate ownership around the world. Journal of Finance, 54, 471-517.

Lachmann, L. (1979) The flow of legislation and the permanence of the legal order In Don Lavoie (Ed.) Expectations and the Meaning of Institutions, Essays in Economics by Ludwig Lachmann. London: Routledge.

Le, S., Kroll, M., \& Walters, B. (2010). The impact of institutional changes on corporate governance mechanisms in transition economies. Journal of Management and Governance, 14, 91-114.

Martin, R. (2002). Politicized managerial capitalism: enterprise structures in postsocialist Central and Eastern Europe. Journal of Management Studies, 39, 823840 .

Meyer, J. W., \& Rowan, R. (1977). Institutional organizations: Formal structure as myth and ceremony. American Journal of Sociology, 83, 440-463. 
McCarthy, D., \& Puffer, S. (1995). Diamonds and rust on Russia's road to privatization. Journal of World Business, 30: 56-69.

McCarthy, D., \& Puffer, S. (2003). Corporate governance in Russia: A framework for analysis. Journal of World Business, 38, 397-416.

McMillan, J., \& Woodruff, C. (2000). Private order under dysfunctional public order. Michigan Law Review, 98, 2421-2458.

Nee, V. (1992). Organizational dynamics of market transition: Hybrid forms, property rights, and mixed economy in China. Administrative Science Quarterly, 37, $1-27$

North, D. C. (1990). Institutions, institutional change and economic performance. Cambridge, MA: Harvard University Press.

Oliver, C. (1991). Strategic responses to institutional processes. Academy of Management Review. 16, 145-179.

Ouchi, W. G. (1979). A conceptual framework for the design of organizational control mechanisms. Management Science, 25, 833-848.

Peng, M. W. (2003). Institutional transitions and strategic choices. Academy of Management Review, 28, 275-296.

Peng, M. W. (2004). Outside directors and firm performance during institutional transitions. Strategic Management Journal, 25, 453-471.

Peng, M. W., \& Heath, P. S. (1996). The growth of the firm in planned economies in transition: Institutions, organizations, and strategic choice. Academy of Management Review, 21, 492-528.

Pfeffer, J., \& Salancik, G. (1978). The external control of organizations: A resource dependence perspective. New York: Harper and Row.

Prowse, S. (1995). Corporate governance in an international perspective: A survey of corporate control mechanisms among large firms in the United States, the United Kingdom, Japan and Germany. Blackwell, MA: Cambridge.

Roe, M. J. (1991). A Political theory of American corporate finance. Columbia Law Review, 91, 1-67.

Seo, M., \& Creed, D. (2002). institutional contradictions, praxis, and institutional change: A dialectical perspective. Academy of Management Review, 27, 222248.

Scott, W. R. (1995). Institutions and organizations. London: Sage.

Shleifer, A., \& Vishny, R. (1997). A survey of corporate governance. Journal of Finance, 52, 737-783.

Stark, D. (1994). Recombinant property in East European capitalism. American Journal of Sociology, 101, 993-1027. 
Suhomlinova, O. O. (1999). Constructive destruction: Transformation of Russian state-owned construction enterprises during market transition. Organization Studies, 20, 451-483.

Tihanyi, L., \& Roath, A. S. (2002). Technology transfer and institutional development in Central and Eastern Europe. Journal of World Business, 37, 188-199.

Williamson, O. E. (1985). The economic institutions of capitalism: Firms, markets, relational contracting. New York: The Free Press.

Williamson, O. E. (1995). The institutions and governance of economic development and reform. Proceedings of the World Bank Annual Conference on Development Economics 1994 (pp. 171-197). Washington: World Bank.

World Bank, (2002). World development report: Building institutions for markets. Washington: World Bank.

Wright, M., Filatotchev, I., Buck, T., \& Bishop, K. (2003). Is stakeholder corporate governance appropriate in Russia? Journal of Management and Governance, 7, 263-290.

Yoshikawa, T., \& Phan, P. H. (2001). Alternative corporate governance systems in Japanese firms: implications for a shift to stockholder-centered corporate governance, Asia Pacific Journal of Management, 18, 183-205.

Young, M., Peng, M. W., Ahlstrom, D., \& Bruton, G. D. (2002). Governing the corporation in emerging economies: A principal-principal perspective. Academy of Management Best Paper Proceedings.

\section{Biographical Sketches of Authors}

Son A. Le is the John Ed Barnes Endowed Professorship in Entrepreneurship at Louisiana Tech University. He received his D.B.A. from Louisiana Tech University. His research interests include entrepreneurship, corporate governance issues and strategies in entrepreneurial contexts and emerging economies.

Mark Kroll is the Dean of the School of Business at the University of Texas at Brownsville and Texas Southmost College. He received his D.B.A. from Mississippi State University. His research interests include firm governance and strategic leadership of entrepreneurial firms.

Bruce A. Walters is the Edward L. Moyers Endowed Professor of Management at Louisiana Tech University. He received his Ph.D. from the University of Texas at Arlington. His current research interests include competitive advantage in dynamic environments, top executive characteristics, corporate governance, strategic decision processes, and business ethics. 